\title{
Facies Analysis and Sedimentary Architecture of Hybrid Event Beds in Submarine Lobes: Insights from the Crocker Fan, NW Borneo, Malaysia
}

\author{
Muhammad Jamil 1,2,*(D), Numair Ahmed Siddiqui ${ }^{1,3}$, Nisar Ahmed ${ }^{1}$ (D), Muhammad Usman ${ }^{4,5}$, \\ Muhammad Umar ${ }^{6}$, Hamad ur Rahim ${ }^{7,8}$ and Qazi Sohail Imran ${ }^{1}$ (D) \\ 1 Department of Geosciences, Universiti Teknologi PETRONAS, Seri Iskandar 32610, Malaysia; \\ numair.siddiqui@utp.edu.my (N.A.S.); nisarpu12@gmail.com (N.A.); qazi_17007588@utp.edu.my (Q.S.I.) \\ 2 Department of Earth Sciences, Abbottabad Campus, COMSATS University Islamabad, \\ Abbottabad 22044, Pakistan \\ 3 Shale Gas Research Group, Institute of Hydrocarbon Recovery, Universiti Teknologi PETRONAS, \\ Seri Iskandar 32610, Malaysia \\ 4 Department of Earth and Environmental Sciences, University of Milano-Bicocca, Piazza Della Scienza 4, \\ 20126 Milano, Italy; usman.pu@outlook.com \\ 5 School of Geosciences, China University of Petroleum (East China), Qingdao 266580, China \\ 6 Department of Earth Sciences, The University of Haripur, Haripur 22620, Pakistan; umarkhan09@yahoo.com \\ 7 Earth Sciences Division, Pakistan Museum of Natural History, Islamabad 44000, Pakistan; \\ hamadrahim@gmail.com \\ 8 Department of Earth Sciences, Quaid-i-Azam University, Islamabad 45320, Pakistan \\ * Correspondence: jamil287@gmail.com
}

Citation: Jamil, M.; Siddiqui, N.A.; Ahmed, N.; Usman, M.; Umar, M.; Rahim, H.u.; Imran, Q.S. Facies Analysis and Sedimentary Architecture of Hybrid Event Beds in Submarine Lobes: Insights from the Crocker Fan, NW Borneo, Malaysia. J. Mar. Sci. Eng. 2021, 9, 1133. https:// doi.org/10.3390/jmse9101133

Academic Editor: Gemma Aiello

Received: 6 August 2021

Accepted: 17 September 2021

Published: 15 October 2021

Publisher's Note: MDPI stays neutral with regard to jurisdictional claims in published maps and institutional affiliations.

Copyright: (c) 2021 by the authors Licensee MDPI, Basel, Switzerland. This article is an open access article distributed under the terms and conditions of the Creative Commons Attribution (CC BY) license (https:// creativecommons.org/licenses/by/ $4.0 /)$.
Abstract: Hybrid event beds represent the combined effect of multiple geological processes, which result in complex depositional geometries and distinct facies distribution in marine environments. Previous work on hybrid event beds highlights the classification, origin, and types of hybrid facies. However, in the present study, we discuss the development of hybrid event beds in submarine lobes with an emphasis on the analysis of proximal to distal, frontal to lateral relationships and evolution during lobe progradation. Detailed geological fieldwork was carried out in the classical deep-marine Late Paleogene Crocker Fan to understand the relationship between the character of hybrid bed facies and lobe architecture. The results indicate that hybrid facies of massive or structureless sandstone with mud clasts, clean to muddy sand, and chaotic muddy sand with oversized sand patch alternations (H1-H3) are well developed in proximal to medial lobes, while distal lobes mainly contain parallel to cross-laminated clean to muddy hybrid facies (H3-H5). Furthermore, lateral lobes have less vertical thickness of hybrid beds than frontal lobes. The development of hybrid beds takes place in the lower part of the thickening upward sequence of lobe progradation, while lobe retrogradation contains hybrid facies intervals in the upper part of stratigraphy. Hence, the development of hybrid beds in submarine lobe systems has a significant impact on the characterization of heterogeneities in deep-marine petroleum reservoirs at sub-seismic levels.

Keywords: facies heterogeneity; hybrid event beds; lobe architecture; north-west Borneo; sedimentological characterization; submarine siliciclastic deposition; West Crocker Formation

\section{Introduction}

Submarine gravity flows are one of the key sedimentary processes responsible for sediment transport, in which a single submarine flow may result in an enormous volume of rock deposition. These sedimentary successions can develop some of the thickest and largest rock accumulations on the planet [1-6]. These density flow deposits have significant petroleum potential and provide valuable information on ancient submarine geological processes in deep-marine environments. The understanding of hybrid bed facies deposited 
by density flows and their heterogeneities is vital for oil and gas potential, especially in submarine siliciclastic deposition [7-9]. A subaqueous gravity flow carrying sediments may consist of various types of flow mechanisms and the transformation of flow may occur while moving downslope under the action of gravity [10]. The characterization of flow is based on the detailed observations of ancient sediment gravity flow deposits, whereby the basinward variations enhance the probabilities of flow transformation [11-13], resulting in composite beds having abrupt textural breaks [14].

Deep-water depositional systems may contain a combination of sediment gravity flows in a single event termed variably by a number of researchers as bipartite-tripartite deposits [15], linked debrites [16], co-genetic debrite-turbidite (CGDT) beds [17], hybrid event beds HEBs [18], hybrid sediment gravity flow deposits [19], intermediate strength cohesive debris flow deposits [20], transitional flow deposits [21], matrix rich sands [22], sand-mud couplet [23], or hybridite [24]. These hybrid event beds can be recognized on a variable scale ( $\mathrm{cm}$ to $\mathrm{m}$ ) in core samples as well as in outcrops [23].

The relative proportion of siliciclastic sediments (grain size and type of sediments) and change in concentration of transporting material in flow determines the evolution of sediment gravity flow processes [25-28]. In addition to this, the fluid turbulence and shear rate significantly influence the flow behavior [12]. A hybrid event bed is considered a type of sediment gravity flow deposit that results from a blend of multiple flow processes including debris flow, turbidity flow, and transitional flows in a single depositional event and generally consisting of basal clean sand followed by muddy sand facies [29-31]. Hybrid event beds are thought to be frequently associated with medial and lateral fringe lobe systems and are further related with prograding lobe settings $[16,19,21,32,33]$ as well as aggradation in basin-plain settings [34]. Hybrid beds are developed when the deceleration of a mud-dominated, highly concentrated sediment flow dispels its energy in medial and distal submarine areas $[1,32,35,36]$.

Recent works on deep-water systems integrate the depositional character of hybrid event beds with the development of lobe systems during the flow transformation in lacustrine and deep-marine basins of Italy [30,34,37,38], the United Kingdom [39], South Africa [40,41], Norway [12], South America [11], Canada [22], Eastern China [36], and Sarawak, Malaysia [42]. In general, these hybrid event beds are present at discrete stratigraphic intervals of lobe systems in a submarine fan environment [38]. Likewise, these alternate clean and muddy sand intervals have considerable impacts on the reservoir characterization and the subsequently, the hydrocarbon production potential of sandy reservoir units $[11,30,43-45]$. Therefore, it is necessary to understand the effect of flow transformation in stratigraphic records of submarine lobes that will substantially influence the reservoir prediction and limit the uncertainties in the stratigraphic data $[23,35,40,43,44]$. The present work emphasizes a huge variety of flow transformation where the hybrid event beds are developed in numerous components of lobe system with irregular sedimentary facies.

Hybrid event beds are commonly present in deep-marine environments, especially in submarine lobe systems, and are also termed as linked debrites having an increase in mud content [46]. However, the maximum vertical thickness of individual lobes mainly depends on the origin of sediments, as channelized lobes normally have less vertical thickness than the non-channelized lobes [47]. The base topography of a basin causes the transformation of flow and controls the development of linked debrites in a deep-marine environment $[34,46,48]$. The development of hybrid event beds in various components of lobes is vital for understanding the paleogeographic reconstruction of submarine fans in deep-water systems and will reduce the ambiguities in the hydrocarbon reservoir potential of deep-marine sandstone intervals $[49,50]$.

The aim of the present study is to associate the various types of hybrid event beds with the characterization of submarine lobes. The key objectives of this work include: (i) the evaluation of hybrid event beds based on submarine lobe processes; (ii) the analysis of spatial distribution of hybrid beds facies with lithological characteristics in several components of lobes; and (iii) to propose a generalized facies model for hybrid event beds 
for submarine lobes of deep-marine fan systems. Seventeen outcrop sections were selected from the study area that are fresh and recently exposed sections due to infrastructural development of Pan-Borneo Highway (Table 1).

Table 1. Selected locations of onshore Sabah. Hybrid event beds are not commonly present throughout all outcrops. A summary of each section is presented in the table below.

\begin{tabular}{|c|c|c|c|c|}
\hline No. & Abbreviation & Location Name & Region & Hybrid Beds Distribution \\
\hline 1 & SUL & Jalan Sulaman & \multirow{5}{*}{ NW Sabah } & Lateral lobe with complete hybrid facies \\
\hline 2 & LPS & Lapasan & & $\begin{array}{l}\text { Distal lobe with all hybrid facies except H2Frontal } \\
\text { lobe with mainly } \mathrm{H} 1 \text { and } \mathrm{H} 3 \text { hybrid facies }\end{array}$ \\
\hline 3 & PQ & Perwira Quarry & & No hybrid beds, sandstones, and shale beds \\
\hline 4 & UU & University Utama, Telipok & & No hybrid facies, mainly massive sandstones \\
\hline 5 & SP & Sepangger port bypass & & Frontal lobes with $\mathrm{H} 1$ and $\mathrm{H} 3$ hybrid facies mainly \\
\hline 6 & UP & University Prima Condo & \multirow{6}{*}{ W Sabah } & Lobe progradation with hybrid beds \\
\hline 7 & JK & Jalan UMS behind the KFC & & $\begin{array}{l}\text { Medial lobes with complete set of hybrid faciesLobe } \\
\text { retrogradation with hybrid beds }\end{array}$ \\
\hline 8 & $\mathrm{JU}$ & Jalan UMS roadside & & $\begin{array}{l}\text { Proximal lobe with hybrid beds } \mathrm{H} 1, \mathrm{H} 2 \text {, and } \\
\text { H5Lateral lobe with } \mathrm{H} 1, \mathrm{H} 3 \text {, and } \mathrm{H} 5 \text { hybrid facies }\end{array}$ \\
\hline 9 & JBN & Jalan Bantayan & & No hybrid beds sandstone and shale intervals \\
\hline 10 & $\mathrm{KM}$ & Kampung Madpai & & No hybrid beds, mainly massive sandstones \\
\hline 11 & SUK & Kampung Sukang & & No hybrid beds, thick to massive sandstone \\
\hline 12 & JLK & Jalan Lok Kawi Pengalat & \multirow{6}{*}{ SW Sabah } & No hybrid beds, massive sandstones \\
\hline 13 & MK & Kampung Mook & & No hybrid beds, massive sandstones, and shales \\
\hline 14 & LKW & Lok Kawi wildlife & & Distal lobe with hybrid facies H1, H3, and H5 \\
\hline 15 & KW & Kampung Kawang & & No hybrid beds, mainly massive shale intervals \\
\hline 16 & PUR & Kampung Purak & & No hybrid beds, mainly turbidites only \\
\hline 17 & $\mathrm{BQ}$ & Benoni Quarry & & No hybrid beds, only debrites and turbidites \\
\hline
\end{tabular}

\section{Geological Settings}

Borneo exhibits complex geological history, particularly during the Tertiary Period when thousands of meters-thick deep-marine sedimentary successions were deposited in an active tectonic regime [51-56]. Active tectonic subduction in Borneo resulted in the closure of paleo-basins and development of ophiolite rocks [57,58]. During the Late Cretaceous, the island arc and tectonic fragments collided with the continental part of the Sunda Plate, forming the depocenter named Sabah Basin that now represents the northern part of Borneo $[52,59,60]$. Thus, NW Borneo is located at the complex geological junction of the South China Sea, the Sunda Shelf, the Java Sea, and the Celebes Sea (Figure 1), where convergent tectonic settings resulted in the Sabah orogenic belt exposing the Tertiary deepwater sediments $[46,53,61-64]$. The NW Sabah Basin mainly consists of the Crocker range or Crocker fold-thrust belt that developed due to the collision of continental plates [65-67].

Tertiary stratigraphy of the Sabah Basin is mainly distributed in two phases, where the first phase of tectonic and sedimentary processes comprised the deposition of the Early Paleogene (Paleocene to Eocene) deep-water sediments of Trusmadi and East Crocker formations. The first phase of deposition was followed by uplifting, erosion, and an unconformable surface termed the Late Eocene Unconformity (LEU). Later, the second Late Paleogene (Late Eocene to Early Miocene) phase was overlain by an unconformity resulting in the deposition of the West Crocker and Temburong formations [62,68]. The upper contact of the West Crocker Formation is marked by the Top Crocker Unconformity (TCU) or the Base Miocene Unconformity (BMU) (Figure 1). The West Crocker Formation 
is representative of a deep-marine fan system $[46,57,62]$ that mainly comprises thick to massive sandstone, interbedded with siltstone and mudstone, interpreted as various components of submarine lobe systems [46,69].

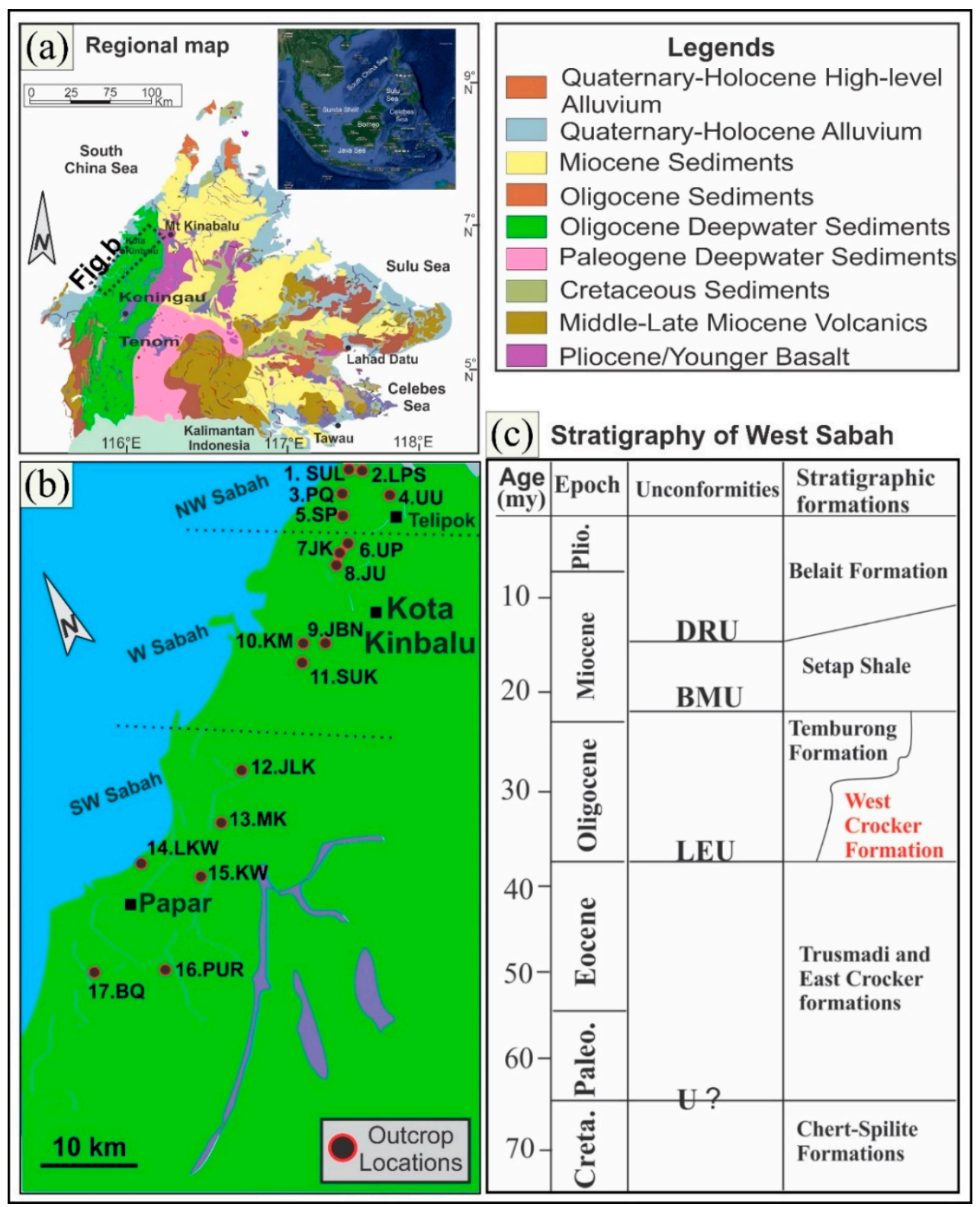

Figure 1. Study area in Sabah, NW Borneo. (a) Map of Borneo with surrounding archipelagos with stratigraphic record in the legend outlined with black rectangle showing the study location of Sabah. (b) Study area with various regions in Sabah selected for the fieldwork, where locations 1-5 are around Telipok (NW Sabah), locations 6-11 around the Kota Kinabalu (West Sabah), and 12-17 around Papar Town (SW Sabah). (c) Stratigraphic position of the sand-rich West Crocker Fan majorly related to the Oligocene age and bound by the Late Eocene Unconformity (LEU) at the base while the upper contact is marked by the Base Miocene Unconformity (BMU).

Previous literature on the Crocker Fan reported that the deep-marine sediments originated from local nearby sources and did not involve long-distance transport. Therefore, these sediments are texturally immature and contain angular to subangular fragments originating from recycled orogen $[51,69,70]$. The texture of sediments is not diverse; however, they contain a wide variety of deep-marine sedimentary successions including mass transport deposits, debrites, high-density turbidites, and low-density turbidites interpreted 
to be the parts of outer, middle, and inner fan environments [46,47,66,69-71]. The origin of linked debrites and co-genetic turbidite-debrite intervals was discussed in the West Crocker Formation with respect to their sedimentological and stratigraphic framework and the spatial distribution of these intervals in the Sabah Basin [46,47]. However, this study reveals the development of hybrid event bed facies with various distributive components of submarine lobe system. The outcrops containing these hybrid event beds are part of the Crocker fold-thrust belt that formed due to convergent tectonic regimes. These rocks were initially deposited in a deep-marine basin with a water depth of more than $2000 \mathrm{~m}$ and later exposed to the surface by uplifting and erosional processes [72,73].

\section{Materials and Methods}

The present work includes detailed geological fieldwork in onshore Sabah to observe the characteristics of hybrid event beds in submarine lobe systems. It is pertinent to mention that these hybrid event beds are not present in every outcrop. Therefore, some key sections of outcrops were selected to understand the facies of hybrid event beds in deep-marine sediments.

\subsection{Data and Fieldwork}

The present work involved detailed geological fieldwork in seventeen locations having more than $1100 \mathrm{~m}$ of stratigraphic thickness exposed from NW (Telipok) to SW (Papar) Sabah, NW Borneo (Figure 1), to find excellent examples of outcrops. As most hybrid event beds are vertically extensive but laterally limited in stratigraphic records, they are not expressed in every exposed section (Figure 2) of deep-marine sedimentary successions. Hence, these hybrid event beds are exposed only in a limited number of locations exposed to sedimentary successions. The selected outcrops range in vertical thicknesses from 31 to $192 \mathrm{~m}$ and are present over $61.2 \mathrm{~km}$ length of transect.

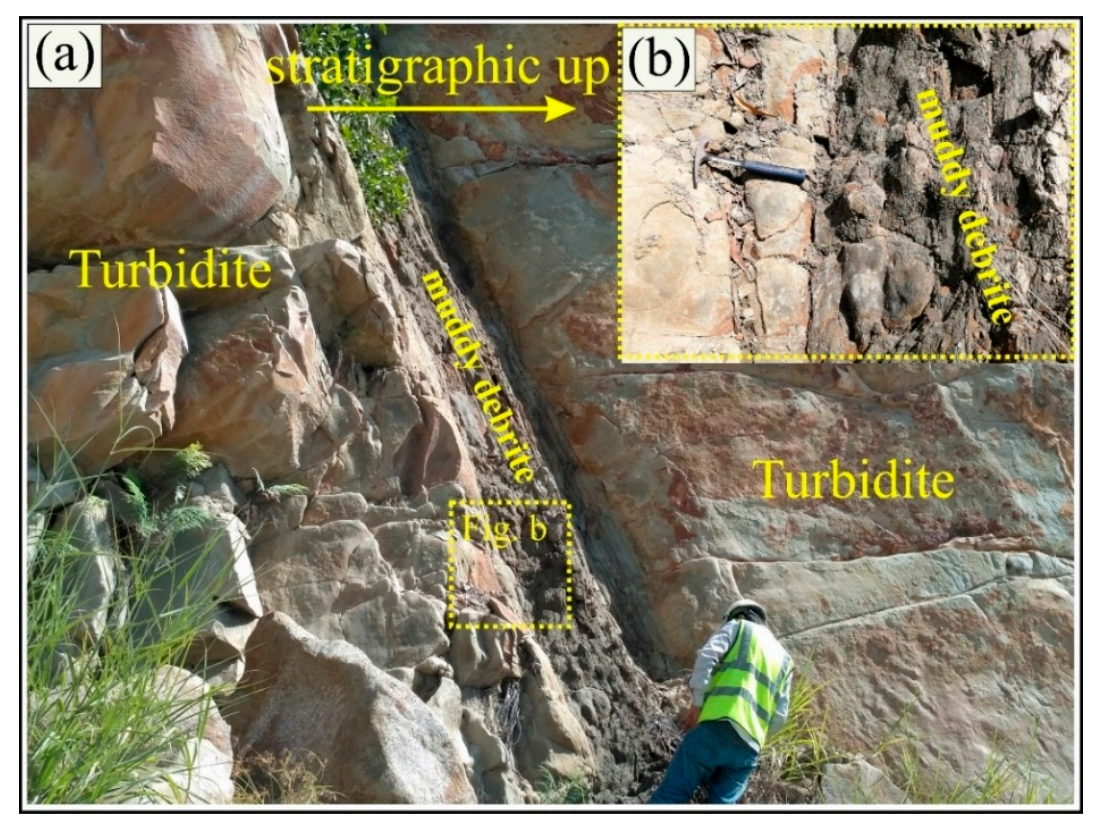

Figure 2. (a) Deep-marine sediments contain various types of deposits as we move stratigraphically from base to top of an exposed section in the Benoni Quarry (BQ), SW Sabah. It is possible to find muddy debrite in between two turbidite sandstone units. (b) An enlarged image of the contact of turbidites and debrite with lack of transformation of flow and, consequently, no expression of hybrid event intervals in this stratigraphic record.

This extensive field study enabled us to compare various types of hybrid facies in deep-marine sedimentary successions. Sedimentary logs supported the discussion to illustrate the development of hybrid event beds in a lobe system and its stratigraphic 
framework. Bed-scale heterogeneities in gravity-flow deposits were analyzed, with emphasis on boundary surfaces of individual beds, variation in grain size, and lithological characteristics. Systematic variations in hybrid units bound by stratigraphic intervals were used to determine the flow characterization in submarine lobe deposits.

\subsection{Hybrid Bed Facies}

Hybrid event beds are classified into five major divisions or facies on the basis of sedimentary features present in each division from base to top and termed as $\mathrm{H} 1$ to $\mathrm{H} 5$ facies [19] as shown in Figure 3. The base of hybrid event bed succession is massive sandstone occasionally containing dewatering structures at the base and floating mud clasts in the upper part of interval, termed as hybrid event bed facies 1 (H1). This division is overlain by a sandy unit with alternating lighter and darker bands developed due to clean and muddy sand deposition, representing hybrid event bed facies 2 (H2). The third hybrid event bed division is a chaotic muddy sand containing abundant mud clasts while some of the sand patches are outsized particles, collectively denoted $\mathrm{H} 3$ facies. A fine sand division comprising parallel or cross laminations is termed hybrid event bed facies 4 (H4). The final depositional unit in the hybrid event bed sequence is a muddy massive unit called hybrid event bed facies 5 or $\mathrm{H} 5$ facies.

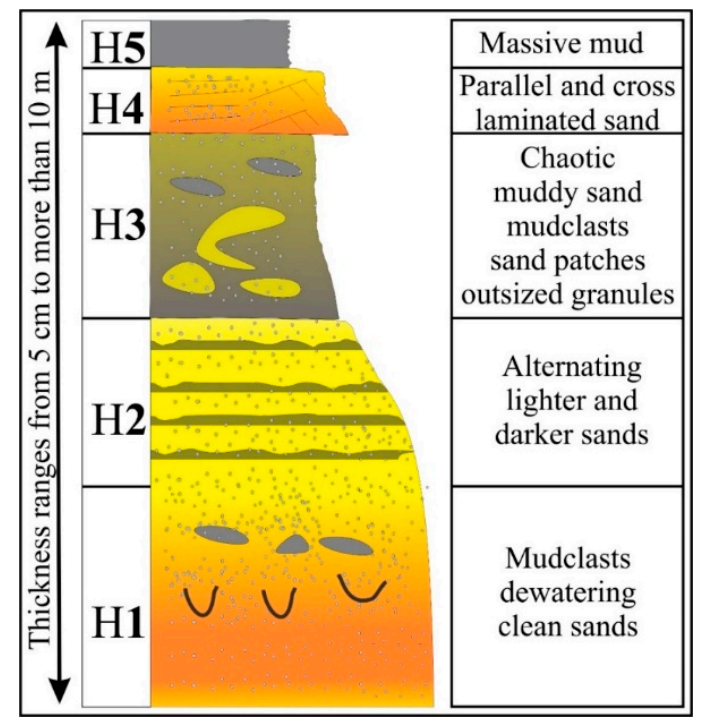

Figure 3. A simple hybrid event bed facies model proposed by Haughton et al. [19], showing five hybrid bed facies or divisions from base $\mathrm{H} 1$ to top $\mathrm{H} 5$. The basal H1 facies comprises massive sand with dewatering and broken mud clasts, the $\mathrm{H} 2$ hybrid event bed facies consists of alternate lighter and darker banded sandstone, H3 has muddy sand with chaotic features both of sand clasts and mud clasts, the $\mathrm{H} 4$ facies is formed with fine sand with parallel and cross laminations, and the $\mathrm{H} 5$ facies is linked with massive mudstone or shale.

These five hybrid event bed facies vary in scale from a few centimeters to about $10 \mathrm{~m}$ in vertical thickness and hence, they can be equally studied in cores as well as in outcrop sections. Moreover, it is quite possible that among these five divisions, one of these divisions only is expressed in less than $10 \mathrm{~cm}$ while other hybrid event bed facies may have more than a meter thickness at the same location. However, all these divisions are not necessarily present in every hybrid event bed. In fact, the presence of all five facies in a single hybrid event is relatively uncommon.

\subsection{Lobe Architecture}

The hierarchy of the lobe system was adopted from Prélat et al. [74] in which the lithological bed or bedset collectively form the lobe element, which is the basic building unit for lobe hierarchy (Figure 4). The beds or bedsets vary in $\mathrm{cm}$ to $\mathrm{m}$ scale that accurately 
integrate with the scale of hybrid event bed $[33,75]$. Therefore, the distribution of hybrid event bed facies at outcrop level represents the lobe element $[39,76]$. Several lobe elements combine to form an individual lobe at a vertical scale of 5-10 $\mathrm{m}$, which is considered the maximum thickness of a hybrid event bed, and these lobes are grouped together in a single lobe complex, and further lobe complexes combine to form a lobe complex set or lobe complex system $[27,77,78]$.

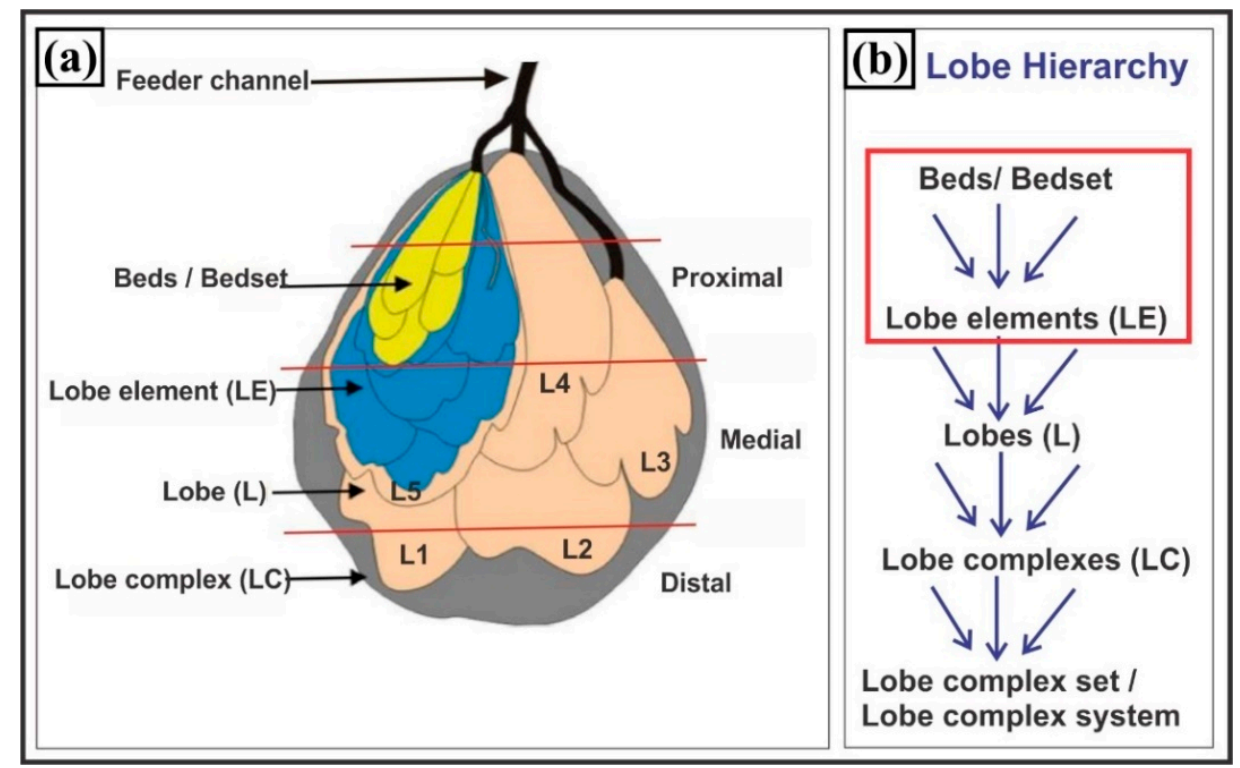

Figure 4. A sketch showing various components of a lobe system from proximal to distal zones. (a) Each lobe has the smallest units of bed or bedset which merge into lobe element (LE). Many lobe elements combine to form an individual lobe (L). These lobes are further stacked into a lobe complex [45,79]. (b) Lobe hierarchy starting from beds or bedset following to form a lobe. The lobe element is the basic building block of a lobe system while the lobe complex set or lobe complex system is the largest entity in lobe hierarchy.

However, our study has not found the hybrid event bed reaching $10 \mathrm{~m}$ on an individual lobe scale. Hence, hybrid event bed divisions are commonly associated with the lobe element and are frequently related with the components of an individual lobe [45]. The occurrence of hybrid beds in a lobe system is common during the transformation of flow from a higher flow regime to a lower flow regime and because of that, these hybrid facies are well-developed in medial lobe settings [18,41]. The dimensions of a lobe in lateral across strike depends on the confined zones in a basin and topographic fluctuations, where confined settings have limited deposition of hybrid beds $[12,33,79]$.

\section{Results and Interpretations}

\subsection{Hybrid Bed Facies in Proximal to Distal Lobes}

\subsubsection{Proximal Lobes}

Proximal lobes having hybrid facies (2-3 m vertical thickness) comprising thick to massive sand vary in grain size from coarse to fine-grained, usually exhibit poor sorting, and may contain water-escape structures ( $\mathrm{H} 1$ facies). The basal division is clean sand frequently overlain by floating mud clast intervals within massive sand divisions. This massive sand constitutes a considerable part of the base of a hybrid event bed and is often overlain by banded sand and sandy mud deposition (H2 facies) (Figure 5). 

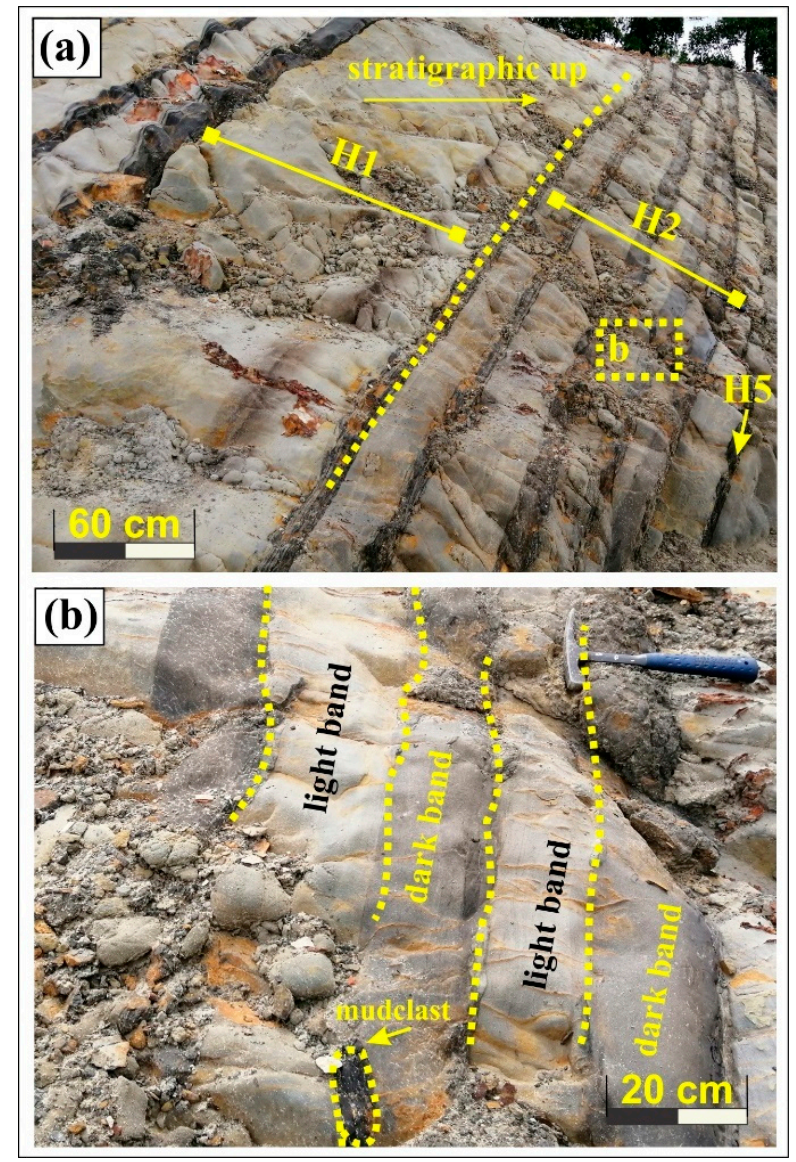

Figure 5. The development of hybrid event bed facies in proximal lobe system. (a) An expression of a sandy hybrid event bed ( $\mathrm{H} 1$ and $\mathrm{H} 2)$ from the base to the top of a sedimentary unit in the Jalan UMS (JU) section, West Sabah, at multimeter scale where the yellow dashed line indicates the facies boundary between $\mathrm{H} 1$ and $\mathrm{H} 2$. (b) An enlarged image of the $\mathrm{H} 2$ hybrid event bed facies containing lighter and darker sand intervals (yellow dashed lines representing the boundary of light and dark bands) with a floating mud clast (labelled in yellow oval-shaped dashed lines) that is relatively uncommon in $\mathrm{H} 2$ facies and was not reported previously.

This banded facies develops due to progressive evolution of flow from fluidized to plastic due to reduced turbulency and more cohesion in flow behavior [80]. These hybrid event beds usually occur in axial or proximal lobe settings [38,42] when the flow transformation takes place. Wedge-shaped bed geometries and clastic muddy injections may also occur in chaotic division [32] or in linked debrites, which are mainly related with proximal lobe settings in rock sections of our study area.

\subsubsection{Medial Lobes}

Medial lobes are ideal avenue for the development of hybrid facies when a sand-rich system is gradually increased in mud content during the phase of deposition. Hence, a complete sequence of hybrid bed facies ( $\mathrm{H} 1$ to $\mathrm{H} 5)$ is likely to develop in the medial lobe system (Figure 6). However, the thicknesses of sandy hybrid event beds (H1 and H2) greatly decrease at the expense of increases in the thickness of muddy hybrid event bed intervals ( $\mathrm{H} 3$ to $\mathrm{H} 5)$. Hence, the thickness of the basal hybrid event bed facies in medial lobes is less $(1-1.5 \mathrm{~m})$ than those in the proximal lobes $(2-3 \mathrm{~m})$. 

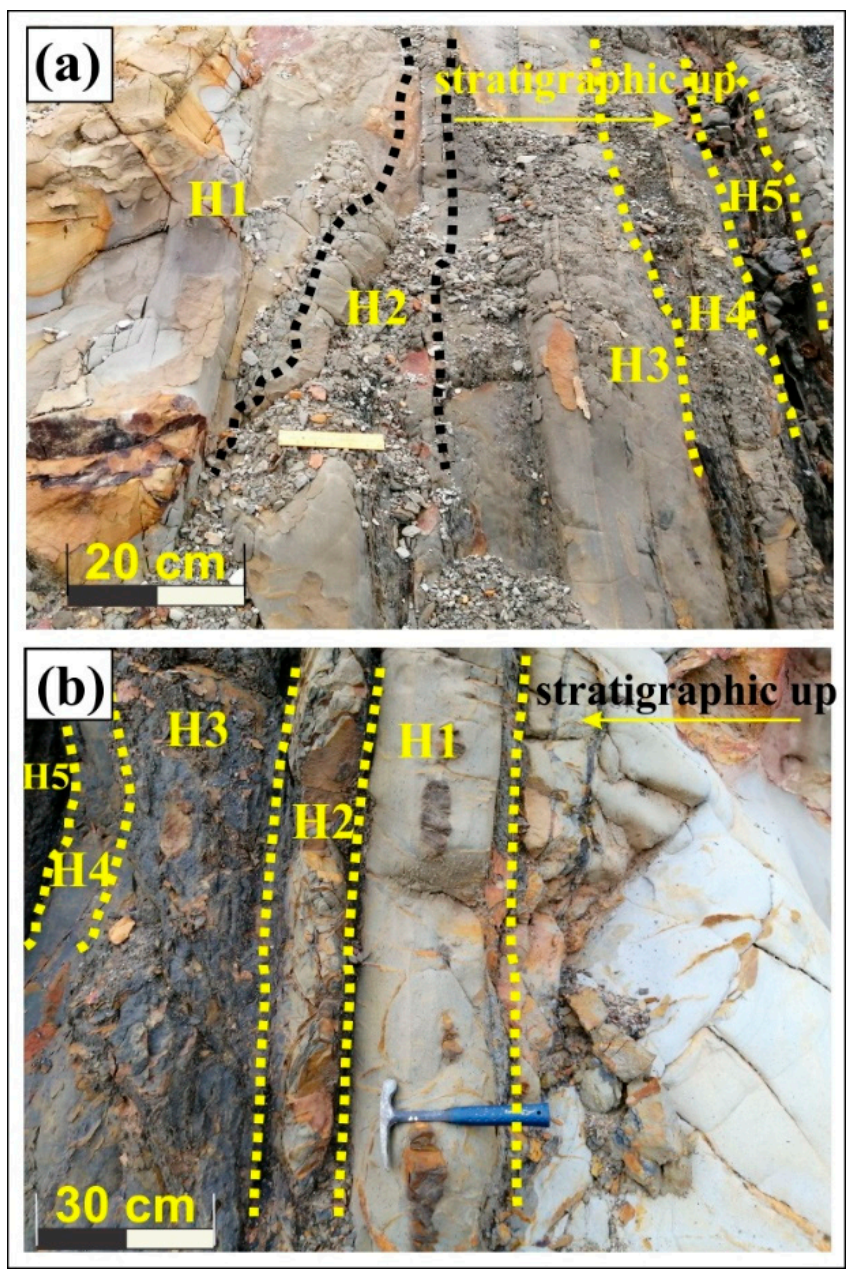

Figure 6. Hybrid bed facies in a medial lobe setting. (a) A complete model of hybrid facies is commonly developed in the medial lobe system, where all the facies are distinctively placed in hybrid event beds. One can easily find facies ranging from $\mathrm{H} 1$ to $\mathrm{H} 5$ from the base to the top, respectively, in the medial lobe exposed in the Sepangger (SP) section, NW Sabah. (b) All hybrid event bed facies (H1 to H5) are developed in the medial lobe component exposed in the Jalan UMS behind the KFC (JK) section, West Sabah.

The gradual loss of coarse-grained sediments in the proximal lobes gradually enriches the clay and silt particles, resulting in the transformation of flow character developing the hybrid event beds in medial lobe settings [44]. Moreover, these deep-marine sandmud couplets are established due to remobilization of sediments during the phase of deposition $[14,23,36]$ which are also termed as the chaotic division of H3 hybrid facies well-developed in the medial lobe settings $[14,23,30,36]$.

\subsubsection{Distal Lobes}

The vertical thickness of hybrid event beds in distal lobe settings relatively decreases ( 0.6 to $1.5 \mathrm{~m}$ ) due to deposited sands in the depositional system. However, they may have formed of thicker residual fine-sand and muddy division of hybrid event beds, while the basal divisions of hybrid event beds ( $\mathrm{H} 1$ and $\mathrm{H} 2$ ) are less developed (Figure 7). There is no banded hybrid division of $\mathrm{H} 2$ in the distal lobe settings. 

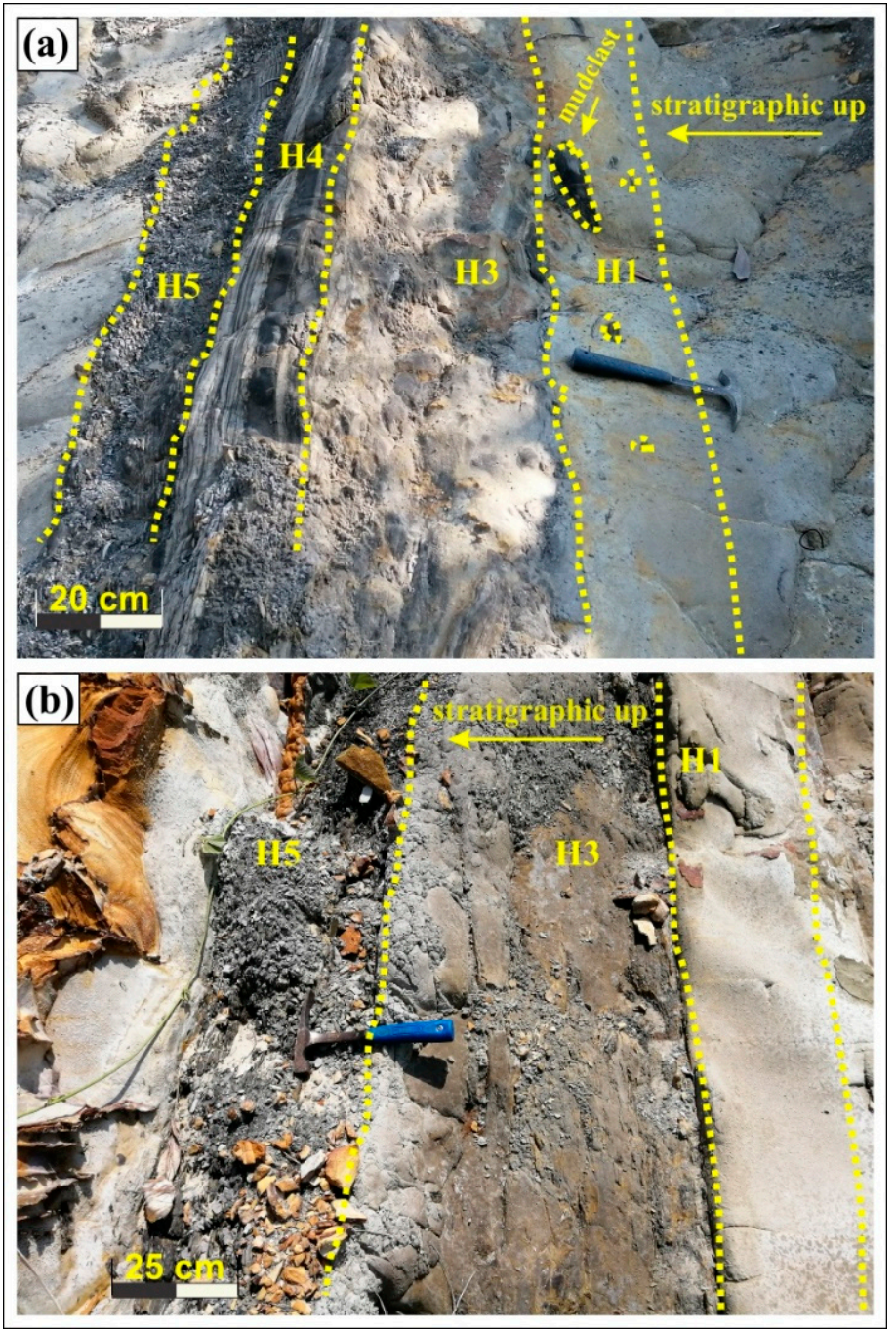

Figure 7. Hybrid event beds interpreted in a distal lobe system. (a) Distal lobe contains more vertical thickness of muddy hybrid event bed facies (H3, H4, and H5) than the proximal and medial lobes moving from the base to the top of sequence in the Lapasan (LPS) section, NW Sabah. (b) The most distal part of the lobe contains the minimum or least vertical thickness of sandy hybrid facies (H1 or $\mathrm{H} 2$ ) where the facies are mainly composed of chaotic intervals of $\mathrm{H} 3$, and mud facies of $\mathrm{H} 5$ in the Lok Kawi wildlife (LKW) section, SW Sabah.

Hybrid event beds are frequently reported in the distal lobe system having abrupt pinch out and wedging in beds due to deceleration of flow $[2,16,18,21,30,81]$. Likewise, linked debrites are usually associated with the proximal and medial settings with higher energy flow, whereas the distal lobes have less vertical thickness of hybrid beds $[18,46]$ as the energy conditions in massive and thick sand packages are already transformed in the proximal and medial lobe settings.

\subsection{Hybrid Bed Facies in Frontal and Lateral Lobes \\ 4.2.1. Frontal Lobes}

Frontal zones of a lobe in the axial component remain with the clay-poor deposition and the lower divisions of hybrid beds are characterized by dewatered sand (H1), overlain by muddy sand intervals mainly in the fringe area (Figure 8). In addition to this, the fringe area of frontal lobes is prone to hybrid events that primarily contain the mud-rich hybrid bed ( $\mathrm{H} 3$ and $\mathrm{H} 5$ facies) because of depositional transition from massive clean sand into muddy sand throughout the deep-marine gravity flow [33]. 


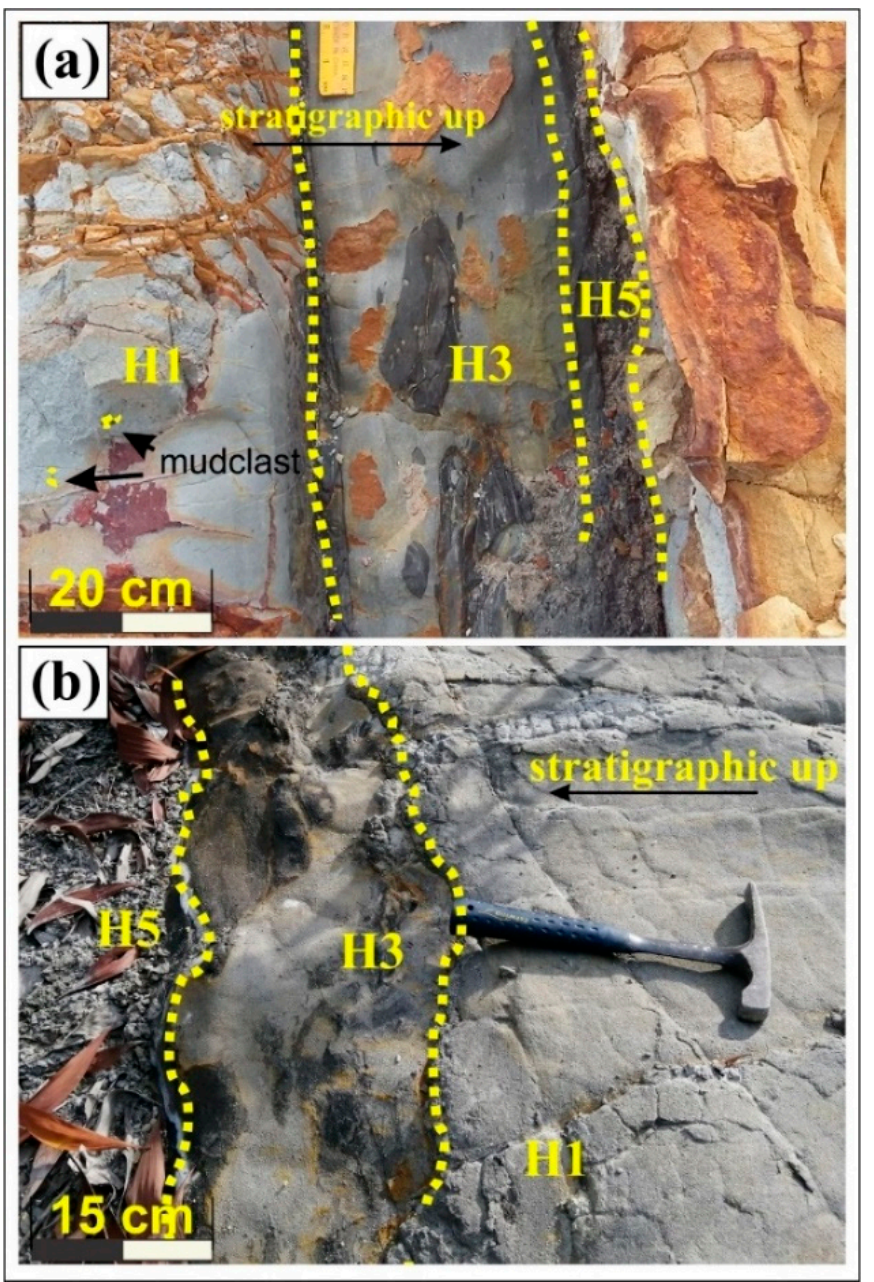

Figure 8. Variable expressions of hybrid event bed facies in frontal lobes. (a) Frontal area of the lobe near to the axis has brief hybrid event bed intervals mainly containing $\mathrm{H} 1$ and $\mathrm{H} 3$ facies with floating mud clasts in the Sepangger (SP) section, NW Sabah. (b) The frontal area away from the axial lobe domain has distinct muddy hybrid facies of $\mathrm{H} 3$ to $\mathrm{H} 5$ and the vertical thickness of the hybrid sequence also increases significantly in the Lapasan (LPS) section, NW Sabah.

\subsubsection{Lateral Lobes}

Lateral lobes are the frequent sites of flow transformation from the lobe axis sideways. These lateral lobes are abundant in sandy hybrid facies associated with broken fragments or mud clasts (Figure 9) while the upper muddy hybrid facies (H3 to H5) are distinctively developed but have less vertical thickness. Lateral lobes have a slight chaotic effect in the depositional phase, which necessitates the formation of $\mathrm{H} 3$ facies in them. The mud clasts of more than $5 \mathrm{~cm}$ are often encompassed in the basal hybrid sandy division (H1) but are relatively smaller sized mud clasts in $\mathrm{H} 3$ facies.

The distribution of hybrid event bed facies greatly depends on the degree of basin confinement as it determines the lobe stacking and dispersal patterns $[33,34,50]$. Lateral lobes exhibit abrupt change in thickness and facies, resulting in less development of vertically thick hybrid event bed facies (Figure 9). It is possible to find the hybrid event bed facies in lateral lobes, but the extension of distinct hybrid event bed facies in lateral lobes is less common, especially in a confined sedimentary system where the flow does not have ample space to establish a distinct and well-developed transitional facies architecture [33,49]. 


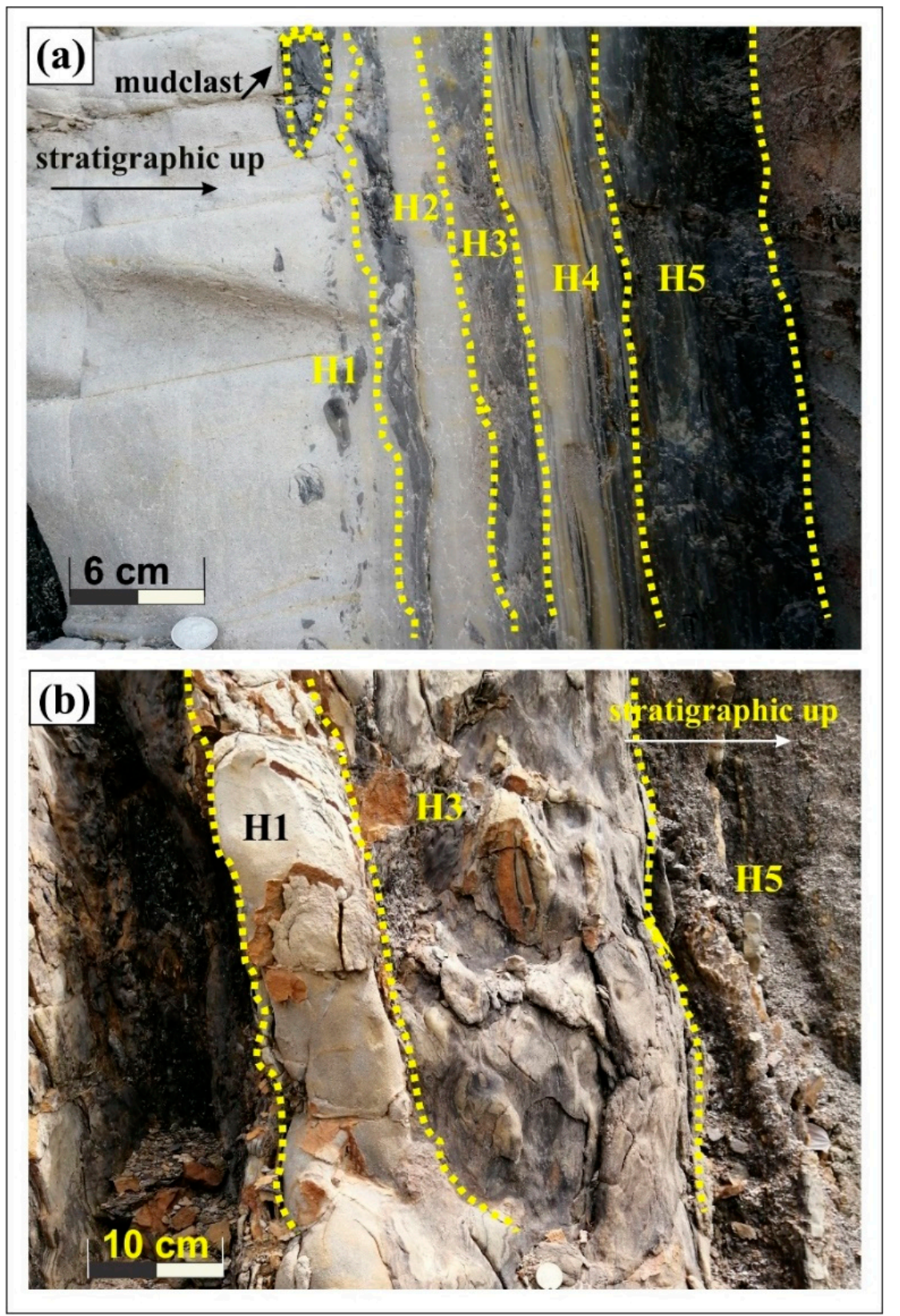

Figure 9. A brief signature of hybrid event beds in lateral lobes. (a) Lateral lobes have distinct brief expressions from $\mathrm{H} 1$ to $\mathrm{H} 5$ facies in the Jalan Sulaman (SUL) section, NW Sabah. (b) Lateral lobes predominantly contain $\mathrm{H} 1$ sandy hybrid intervals overlying a minor component of $\mathrm{H} 3$ and $\mathrm{H} 5$ facies, while moving from the base to the top in a stratigraphic succession exposed in the Jalan UMS (JU) section, West Sabah.

\subsection{Hybrid Bed Facies in Lobe Progradation}

Lobe progradation is a fluctuating geological process that mainly depends on sediment influx, variation in transport distance, and change in relative sea level. Normally, the sandrich depositional units with a thickening upward cycle are indicative of lobe progradation (Figure 10). These hybrid flows are spatially distributed in the form of complex internal rheology $[21,31,40,76,81]$. 


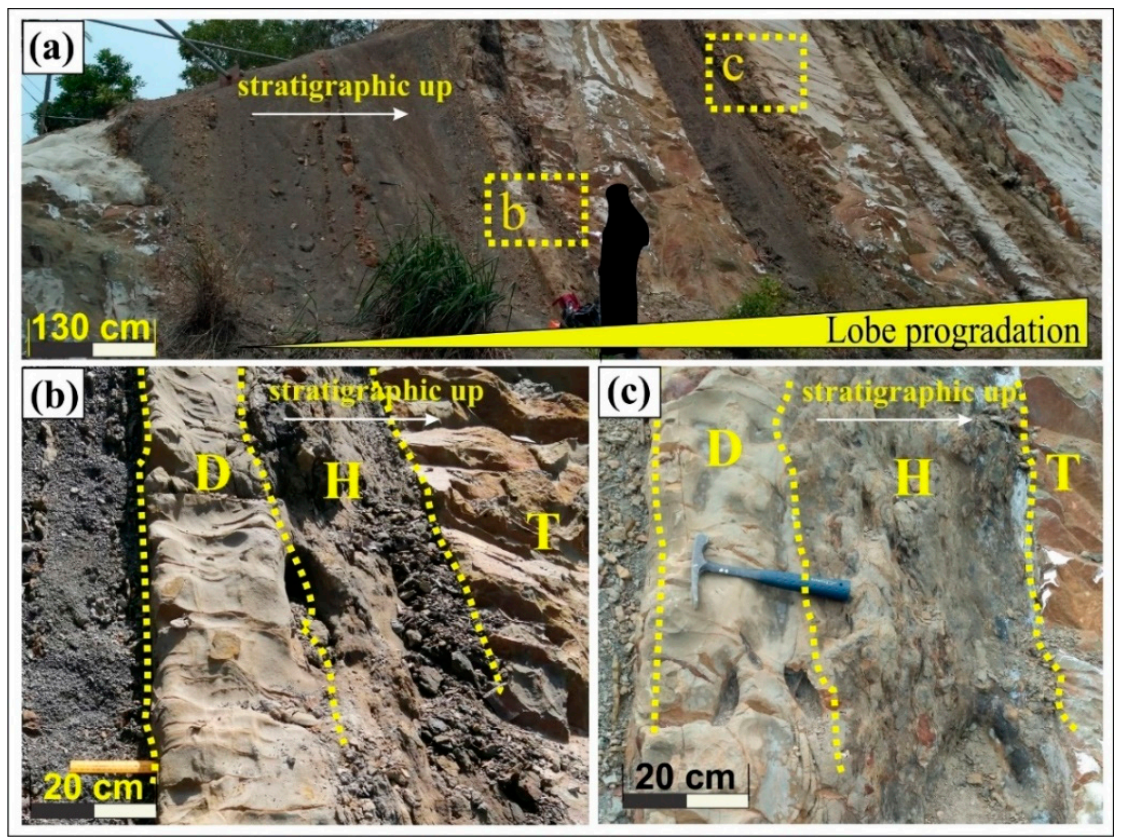

Figure 10. Relative position of hybrid beds in lobe progradation. (a) A thickening upward cycle in the Universiti Prima Condo (UP) section, West Sabah, where the vertical thickness of a massive shale is gradually reduced from base to top. Shaded image of a $173 \mathrm{~cm}$ tall person is shown as a vertical scale. (b) Massive shale overlain by debrite (D), hybrid event bed (H), and then massive sandy turbidite $(\mathrm{T})$ present in the lower part of prograding lobe. (c) A second hybrid event bed $(\mathrm{H})$ between debrite $(\mathrm{D})$ and turbidite $(\mathrm{T})$ is present in lobe progradation.

Hybrid event beds with variable facies divisions are more often associated at the base of a prograding lobe pattern, mainly in an unconfined lobe setting [32,41,45]. These hybrid beds are sporadically distributed in a compensational stacking pattern while these hybrid event beds are mainly present at the top of the retrogradational sequence (Figure 11) of a lobe system [41].
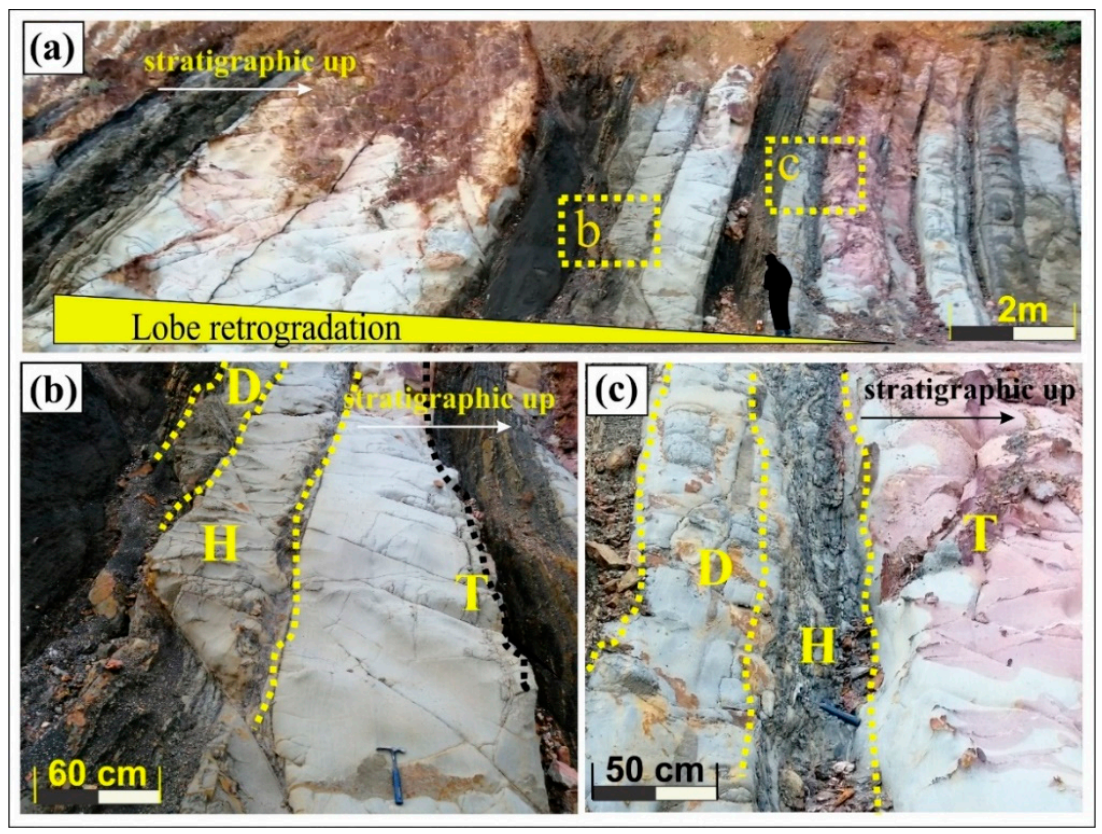

Figure 11. The presence of hybrid event beds during the lobe retrogradation in the Jalan UMS behind 
the KFC (JK), West Sabah. (a) Massive, amalgamated sandstone (of more than $3 \mathrm{~m}$ in thickness) overlain by thick to medium sand units from the base to the top where the hybrid event beds are present in the upper part of sequence. Shaded image of a $169 \mathrm{~cm}$ tall person is used as a vertical scale. (b) The expression of a hybrid event bed $(\mathrm{H})$ unit bounded by debrite (D) at the base and turbidite (T) at the top of sequence. (c) Another chaotic hybrid division $(\mathrm{H})$ present between sandy debrite (D) to turbidite $(\mathrm{T})$ in the upper part of lobe retrogradation.

\section{Discussion}

\subsection{Lithological Heterogenerities in Hybrid Beds and Reservoir Potential}

The heterogeneity of hybrid event bed facies adversely hampered the sandy reservoir. The broken clasts revealed in the $\mathrm{H} 1$ and $\mathrm{H} 3$ divisions would reduce the lateral and vertical connectivity of reservoir [82]. The upper hybrid event bed facies (H3 and H5) are rich in mud which would negatively influence reservoir intervals. The facies of $\mathrm{H} 2$ alternate in regular lighter and darker bands due to mud content distribution to less permeable zones in sandy intervals, destroying vertical migrations of fluids in reservoir units.

The scale of heterogeneity should also be considered while addressing the siliciclastic petroleum reservoirs. These hybrid beds are 1-3 $\mathrm{m}$ in vertical thickness which is generally not resolved in seismic data. It is quite possible that a massive sandstone interval on a seismic section may contain single or multiple hybrid event beds. According to seismic data, one can easily interpret an interval as a potential reservoir, but actually, the reservoir potential is significantly varied due to the presence of hybrid bed facies. The drilling core data and equivalent outcrop stratigraphy would better give a better insight about the potential of these sandstone reservoirs.

\subsection{Distribution of Hybrid Bed Facies}

It is vital to understand the distribution of hybrid event bed facies in submarine lobe systems to evaluate the reservoir potential of deep-marine sand intervals and precise input for reservoir modelling. The size of floating mud clasts is reduced during the flow from proximal to distal zones where large mud clasts in $\mathrm{H} 3$ are present in the proximal component of a lobe while small mud clasts are present in the distal lobe settings $[30,83,84]$. Dewatering in the sandy unit may act as lubrication for the mixture of muddy flow, thus forming a sand-mud couplet similar to a turbidite-debrite couplet in a depositional record $[23,42]$.

Generally, the distribution of hybrid event bed facies from the proximal to distal lobes are significantly variable with respect to scale and type of hybrid event bed facies [38]. Proximal lobes have multimeter beds of hybrid events which mainly contain basal facies (H1 and H2) while medial lobes have the maximum distribution of all hybrid event beds (H1 to H5), as shown in Figure 12. However, distal lobes only contain the upper hybrid event bed facies (H3 and H5) with vertical thicknesses of less than one meter. The distal lobes may contain a small proportion of the basal sandy hybrid event beds ( $\mathrm{H} 1$ and $\mathrm{H} 2)$ only in the fringe area while distal fringe has the least fraction of basal hybrid facies (H1 and $\mathrm{H} 3$ ).

\subsection{Geodynamic Evolution of Hybrid Beds}

The development of hybrid bed facies is highly influenced by frontal and lateral lobe settings. The frontal lobes initially deposit coarse sandstones and there is a gradual evolution of flow conditions. The dynamic model of frontal lobes suggests the flow transformation away from the lobe axis in fringe area $[39,81,84]$. However, the spreading of sediments in lateral lobes starts from an off-axis area that provides a small avenue for the transition of flow and the deposition of hybrid bed facies. It is crucial to understand the role of confinement, especially in lateral lobes where an unconfined basin floor provides ample accommodation space for the well-developed hybrid bed sequence [32]. Hence, hybrid bed facies are frequently associated with boundary conditions of frontal lobes in general and settings of lateral lobes, especially. 


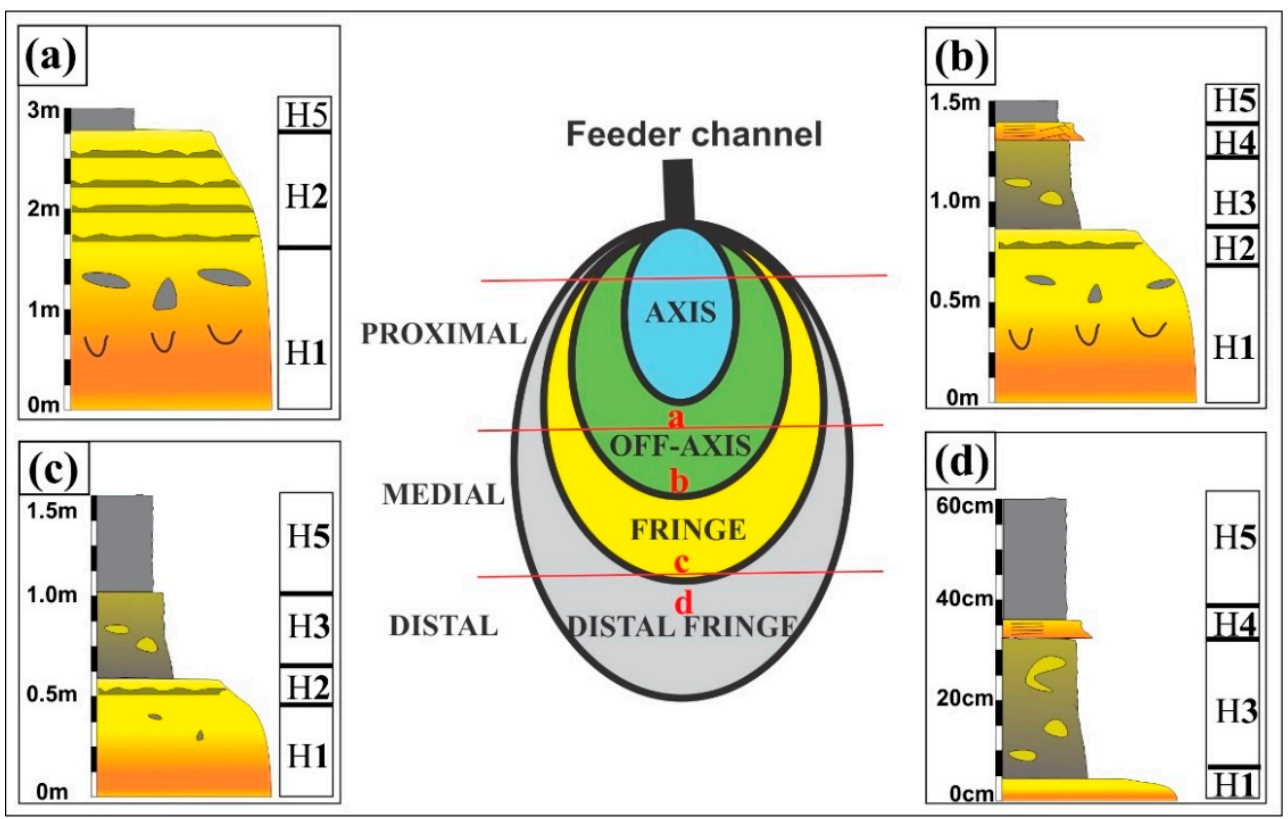

Figure 12. Distribution of hybrid facies from proximal to distal lobes. (a) Proximal lobes contain a major chunk of sands contained mainly $\mathrm{H} 1$ and $\mathrm{H} 2$ facies with thin caps of muds (H5). (b) A complete sequence of hybrid beds (H1 to H5) in a medial lobe. (c) Distal lobe in the fringe area contains small sandy hybrid event bed facies (H1-H2) but mainly comprises muddy upper facies of hybrid event bed. (d) The most distal part of lobe contains muddy hybrid event bed facies with total hybrid sequence less than one meter.

Hybrid event beds are associated with lobe progress as there is an evolution of flow conditions during lobe deposition [38]. The position of a hybrid event bed is the transition zone when a flow changes its velocity either to a higher flow regime or a lower flow regime $[39,84]$. In the case of lobe progradation, when a sand-rich sedimentary succession gradually gains energy and the shale and thin sandstone units are overlain by a thickening upward sequence, the hybrid beds are generally developed in the lower part of the lobe progradation sequence $[40,43,81,85]$ (Figure 13). However, during lobe retrogradation or cessation, the hybrid beds are frequently present in the upper part of thinning upward stratigraphy due to the loss of energy from massive sandstone deposition to shale and thin sandstone intervals [45].

\subsection{Hybrid Event Beds in Sand-Rich Deep-Marine Fan}

The Crocker Fan is considered as one of the most classical examples of a sand-rich deepmarine fan environment where the hybrid event beds are less common in the stratigraphic record $[47,79]$. This sand-dominated deposition is mainly characterized by a debriteturbidite system while hybrid event beds are only present in fewer parts of the fan lobe architecture [38]. Therefore, this study emphasizes the facies of hybrid event beds in a sandrich fan system and the distribution of hybrid facies could vary in sand-mud mixed fan and fine-grained shaly fan environments [29]. Based on lobe components, these hybrid beds could possibly be more common in a mixed sand-mud fan deposition where changes in energy conditions and transformation of flow are frequent due to the evolution of sediment supply, resulting in the formation of hybrid beds at discrete stratigraphic intervals. 


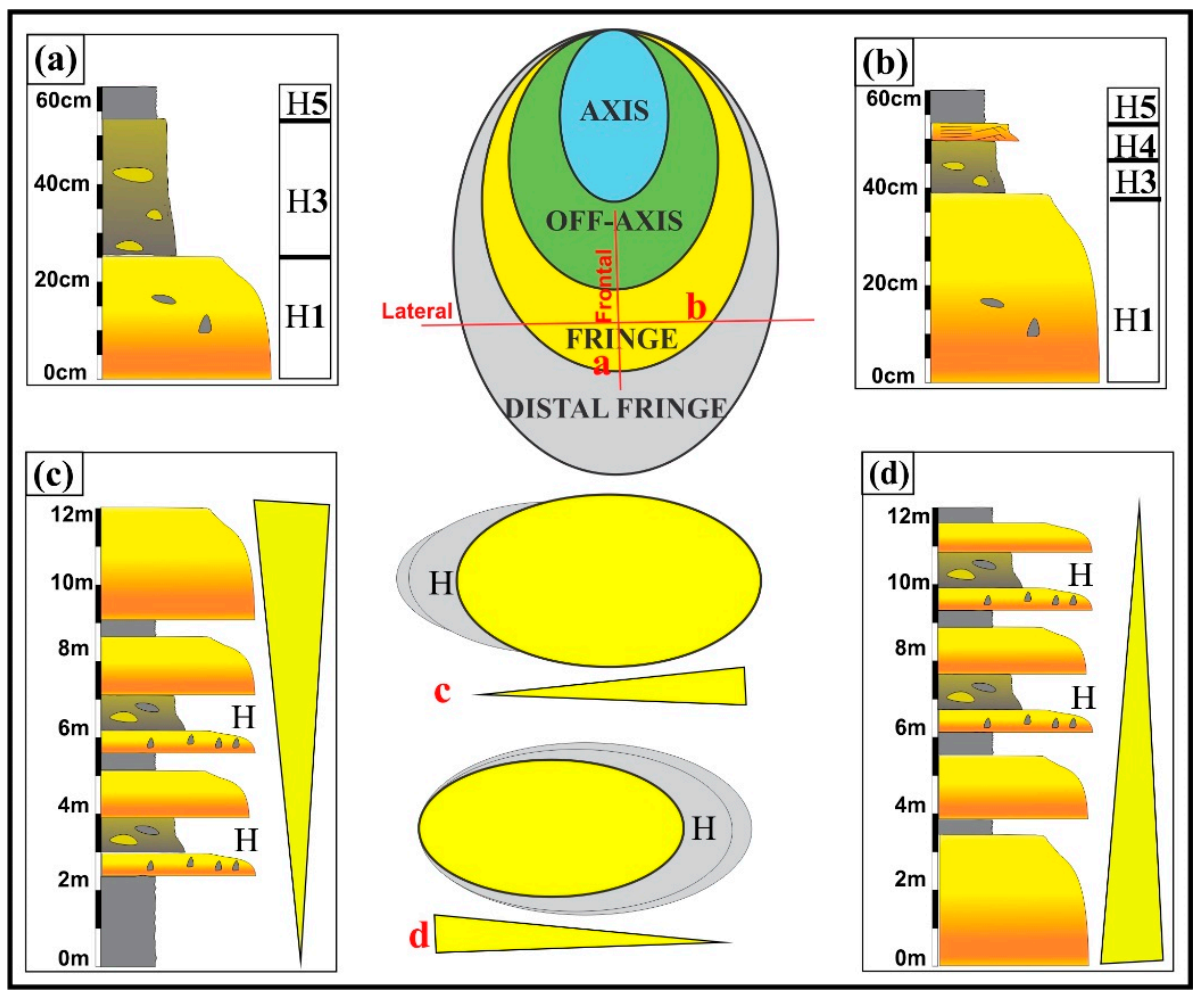

Figure 13. Distribution of hybrid facies. (a) Frontal lobes with incomplete hybrid facies. (b) clean sand (H1) and muddy sand (H3) facies in lateral lobes. (c) Hybrid bed facies in lobe progradation with hybrid beds in the lower part. (d) lobe retrogradation with hybrid beds in the upper part of the lobe.

\section{Conclusions}

The major highlights from this work on facies heterogeneity of hybrid event beds in submarine lobe components distributed along the Crocker Fan System of Sabah are summarized as follows:

1. The sedimentary facies of hybrid events exhibit rapid internal variability in geometry and divisions, characteristic of hybrid event beds in a deep-water system. These variations are typically developed due to numerous forms of basin configuration and transitional flow processes in a depositional environment.

2. It is quite possible that deep-marine sedimentary succession may be devoid of any hybrid event bed facies, especially in the most proximal and the most distal parts of lobes, where the chances of flow transformation are minimum and consequently, no hybrid event beds are formed in these domains.

3. Occasionally, the proximal lobes have multimeter vertical thickness with sandy hybrid event bed facies (H1 and $\mathrm{H} 2$ ), medial lobes have complete sedimentary facies succession of hybrid event bed sequence (H1 to H5), while the distal lobes predominantly contain only muddy hybrid event beds ( $\mathrm{H} 3$ and $\mathrm{H} 5)$ ranging in total thickness from 0.6 to $1.5 \mathrm{~m}$ of a complete hybrid event bed sequence.

4. Frontal lobes are formed of sediments with variable facies distribution including H1 and $\mathrm{H} 3$ in the innermost axial area, while they include a more-developed chaotic division (H3) away from the proximal domain.

5. The development of hybrid event beds is dependent on flow transformation and the zone of transition in a flow event. The gradual transformation of flow favors the deposition of a hybrid sequence while abrupt changes in flow may diminish the chances of hybrid bed deposition.

6. Deep-water sedimentary deposition commonly comprises a fan lobe system and is occasionally associated with hybrid bed facies. Muddy sandstone and clay-rich 
hybrid event bed facies adversely affect the reservoir potential of sandy lobe intervals. This will significantly hinder the pore network and connectivity for lateral and vertical migration of fluids from reservoirs.

Author Contributions: Conceptualization, M.J. and N.A.S.; methodology, M.J. and N.A.; software, M.U. (Muhammad Usman); validation, M.J., N.A. and M.U. (Muhammad Umar); formal analysis, M.J. and Q.S.I.; investigation, M.J. and N.A.S.; resources, M.J. and N.A.S.; data curation, H.u.R. and M.U. (Muhammad Usman); writing—original draft preparation, M.J.; writing—review and editing, N.A.S., H.u.R. and M.U. (Muhammad Umar); visualization, M.J., N.A.S. and M.U. (Muhammad Usman); supervision, N.A.S.; project administration, N.A.S. and M.J.; funding acquisition, N.A.S. All authors have read and agreed to the published version of the manuscript.

Funding: The research was funded by the Fundamental Research Grant of the Ministry of Higher Education (MoHE) Malaysia (project ID 16880, reference code FRGS/1/2019/STG09/UTP/03/1), Petroleum Research Fund (PRF) cost number 0153AB-A33 awarded to Eswaran Padmanabhan, YUTP-FRG 1/2021 (RG2021-0927) and YUTP 015LC0-363.

Institutional Review Board Statement: Not applicable.

Informed Consent Statement: Not applicable.

Data Availability Statement: The data presented in this study are available on request from the corresponding author.

Acknowledgments: The authors are thankful to the faculty and staff of Shale Gas Research Group and Department of Geosciences especially Abdul Hadi Abd Rahman, Universiti Teknologi PETRONAS, Malaysia for technical support during geological fieldwork. The comments and feedback from four anonymous reviewers significantly improved the manuscript.

Conflicts of Interest: The authors declare no conflict of interest.

\section{References}

1. Li, S.; Zhu, X.; Li, S.; Gong, C.; Pan, R.; Chen, H. Trigger mechanisms of gravity flow deposits in the Lower Cretaceous lacustrine rift basin of Lingshan Island, Eastern China. Cretac. Res. 2020, 107, 104269. [CrossRef]

2. Talling, P.J.; Masson, D.G.; Sumner, E.J.; Malgesini, G. Subaqueous sediment density flows: Depositional processes and deposit types. Sedimentology 2012, 59, 1937-2003. [CrossRef]

3. Imran, Q.S.; Siddiqui, N.A.; Latif, A.H.A.; Bashir, Y.; Ali, A.A.A.S.; Jamil, M. Integrated well data and 3D seismic inversion study for reservoir delineation and description. Bull. Geol. Soc. Malays. 2020, 70, 209-220. [CrossRef]

4. Imran, Q.S.; Siddiqui, N.A.; Latiff, A.H.; Bashir, Y.; Khan, M.; Qureshi, K.; Al-Masgari, A.A.; Ahmed, N.; Jamil, M. Automated Fault Detection and Extraction under Gas Chimneys Using Hybrid Discontinuity Attributes. Appl. Sci. 2021, 11, 7218. [CrossRef]

5. Usman, M.; Siddiqui, N.A.; Garzanti, E.; Jamil, M.; Imran, Q.S.; Ahmed, L. 3-D seismic interpretation of stratigraphic and structural features in the Upper Jurassic to Lower Cretaceous sequence of the Gullfaks Field, Norwegian North Sea: A case study of reservoir development. Energy Geosci. 2021. [CrossRef]

6. Banerjee, A.; Ahmed Salim, A.M. Stratigraphic evolution of deep-water Dangerous Grounds in the South China Sea, NW Sabah Platform Region, Malaysia. J. Pet. Sci. Eng. 2021, 201, 108434. [CrossRef]

7. Cullis, S.; Patacci, M.; Colombera, L.; Bührig, L.; McCaffrey, W.D. A database solution for the quantitative characterisation and comparison of deep-marine siliciclastic depositional systems. Mar. Pet. Geol. 2019, 102, 321-339. [CrossRef]

8. Galy, V.; France-Lanord, C.; Beyssac, O.; Faure, P.; Kudrass, H.; Palhol, F. Efficient organic carbon burial in the Bengal fan sustained by the Himalayan erosional system. Nature 2007, 450, 407-410. [CrossRef]

9. Hunt, J.E.; Wynn, R.B.; Masson, D.G.; Talling, P.J.; Teagle, D.A.H. Sedimentological and geochemical evidence for multistage failure of volcanic island landslides: A case study from Icod landslide on north Tenerife, Canary Islands. Geochem. Geophys. Geosyst. 2011, 12. [CrossRef]

10. Zhao, Y.; Wang, H.; Yan, D.; Jiang, P.; Chen, S.; Zhou, J.; Ma, J.; Qin, C.; He, J.; Zhao, Y. Sedimentary characteristics and model of gravity flows in the eocene Liushagang Formation in Weixi'nan depression, South China Sea. J. Pet. Sci. Eng. 2020, 190, 107082. [CrossRef]

11. Dodd, T.J.H.; McCarthy, D.J.; Richards, P.C. A depositional model for deep-lacustrine, partially confined, turbidite fans: Early Cretaceous, North Falkland Basin. Sedimentology 2019, 66, 53-80. [CrossRef]

12. Southern, S.J.; Kane, I.A.; Warchoł, M.J.; Porten, K.W.; McCaffrey, W.D. Hybrid event beds dominated by transitional-flow facies: Character, distribution and significance in the Maastrichtian Springar Formation, north-west Vøring Basin, Norwegian Sea. Sedimentology 2017, 64, 747-776. [CrossRef] 
13. Talling, P.J.; Wynn, R.B.; Masson, D.G.; Frenz, M.; Cronin, B.T.; Schiebel, R.; Akhmetzhanov, A.M.; Dallmeier-Tiessen, S.; Benetti, S.; Weaver, P.P.E.; et al. Onset of submarine debris flow deposition far from original giant landslide. Nature 2007, 450, 541-544. [CrossRef]

14. Stow, D.; Smillie, Z. Distinguishing between Deep-Water Sediment Facies: Turbidites, Contourites and Hemipelagites. Geosciences 2020, 10, 68. [CrossRef]

15. Sohn, Y.K. Depositional Processes of Submarine Debris Flows in the Miocene Fan Deltas, Pohang Basin, SE Korea with Special Reference to Flow Transformation. J. Sediment. Res. 2000, 70, 491-503. [CrossRef]

16. Haughton, P.D.W.; Barker, S.P.; McCaffrey, W.D. 'Linked' debrites in sand-rich turbidite systems-Origin and significance. Sedimentology 2003, 50, 459-482. [CrossRef]

17. Talling, P.J.; Amy, L.A.; Wynn, R.B.; Peakall, J.; Robinson, M. Beds comprising debrite sandwiched within co-genetic turbidite: Origin and widespread occurrence in distal depositional environments. Sedimentology 2004, 51, 163-194. [CrossRef]

18. Hodgson, D.M. Distribution and origin of hybrid beds in sand-rich submarine fans of the Tanqua depocentre, Karoo Basin, South Africa. Mar. Pet. Geol. 2009, 26, 1940-1956. [CrossRef]

19. Haughton, P.; Davis, C.; McCaffrey, W.; Barker, S. Hybrid sediment gravity flow deposits—Classification, origin and significance. Mar. Pet. Geol. 2009, 26, 1900-1918. [CrossRef]

20. Talling, P.J.; Malgesini, G.; Sumner, E.J.; Amy, L.A.; Felletti, F.; Blackbourn, G.; Nutt, C.; Wilcox, C.; Harding, I.C.; Akbari, S. Planform geometry, stacking pattern, and extrabasinal origin of low strength and intermediate strength cohesive debris flow deposits in the Marnoso-arenacea Formation, Italy. Geosphere 2012, 8, 1207-1230. [CrossRef]

21. Kane, I.A.; Pontén, A.S.M. Submarine transitional flow deposits in the Paleogene Gulf of Mexico. Geology 2012, 40, 1119-1122. [CrossRef]

22. Terlaky, V.; Arnott, R.W.C. Matrix-rich and associated matrix-poor sandstones: Avulsion splays in slope and basin-floor strata. Sedimentology 2014, 61, 1175-1197. [CrossRef]

23. Koo, W.M.; Mohrig, D.; Buttles, J.; Sturmer, D.; Pontén, A.; Hess, T. Sand-mud couplets deposited by spontaneous remobilization of subaqueous transitional flows. Sedimentology 2020, 67, 78-95. [CrossRef]

24. Shanmugam, G. Deep-Water Processes and Deposits. In Encyclopedia of Geology; Elsevier: Amsterdam, The Netherlands, 2020.

25. Lowe, D.R.; Guy, M. Slurry-flow deposits in the Britannia Formation (Lower Cretaceous), North Sea: A new perspective on the turbidity current and debris flow problem. Sedimentology 2000, 47, 31-70. [CrossRef]

26. Baas, J.H.; Best, J.L.; Peakall, J. Depositional processes, bedform development and hybrid bed formation in rapidly decelerated cohesive (mud-sand) sediment flows. Sedimentology 2011, 58, 1953-1987. [CrossRef]

27. Doughty-Jones, G.; Mayall, M.; Lonergan, L. Stratigraphy, facies, and evolution of deep-water lobe complexes within a saltcontrolled intraslope minibasin. AAPG Bull. 2017, 101, 1879-1904. [CrossRef]

28. Al-Masgari, A.A.; Elsaadany, M.; Siddiqui, N.A.; Latiff, A.H.; Bakar, A.A.; Elkurdy, S.; Hermana, M.; Babikir, I.; Imran, Q.S.; Adeleke, T. Geomorphological Geometries and High-Resolution Seismic Sequence Stratigraphy of Malay Basin's Fluvial Succession. Appl. Sci. 2021, 11, 5156. [CrossRef]

29. Baker, M.L.; Baas, J.H. Mixed sand-mud bedforms produced by transient turbulent flows in the fringe of submarine fans: Indicators of flow transformation. Sedimentology 2020, 67, 2645-2671. [CrossRef]

30. Fonnesu, M.; Haughton, P.; Felletti, F.; McCaffrey, W. Short length-scale variability of hybrid event beds and its applied significance. Mar. Pet. Geol. 2015, 67, 583-603. [CrossRef]

31. Patacci, M.; Marini, M.; Felletti, F.; Di Giulio, A.; Setti, M.; McCaffrey, W. Origin of mud in turbidites and hybrid event beds: Insight from ponded mudstone caps of the Castagnola turbidite system (north-west Italy). Sedimentology 2020, 67, $2625-2644$. [CrossRef]

32. Fonnesu, M.; Felletti, F.; Haughton, P.D.W.; Patacci, M.; McCaffrey, W.D. Hybrid event bed character and distribution linked to turbidite system sub-environments: The North Apennine Gottero Sandstone (north-west Italy). Sedimentology 2018, 65, 151-190. [CrossRef]

33. Spychala, Y.T.; Hodgson, D.M.; Prélat, A.; Kane, I.A.; Flint, S.S.; Mountney, N.P. Frontal and Lateral Submarine Lobe Fringes: Comparing Sedimentary Facies, Architecture and Flow Processes. J. Sediment. Res. 2017, 87, 75-96. [CrossRef]

34. Marini, M.; Milli, S.; Ravnås, R.; Moscatelli, M. A comparative study of confined vs. semi-confined turbidite lobes from the Lower Messinian Laga Basin (Central Apennines, Italy): Implications for assessment of reservoir architecture. Mar. Pet. Geol. 2015, 63, 142-165. [CrossRef]

35. Talling, P.J. Hybrid submarine flows comprising turbidity current and cohesive debris flow: Deposits, theoretical and experimental analyses, and generalized models. Geosphere 2013, 9, 460-488. [CrossRef]

36. Yang, T.; Cao, Y.; Friis, H.; Liu, K.; Wang, Y. Origin and evolution processes of hybrid event beds in the Lower Cretaceous of the Lingshan Island, Eastern China. Aust. J. Earth Sci. 2018, 65, 517-534. [CrossRef]

37. Fonnesu, M.; Patacci, M.; Haughton, P.D.W.; Felletti, F.; McCaffrey, W.D. Hybrid Event Beds Generated By Local Substrate Delamination on A Confined-Basin Floor. J. Sediment. Res. 2016, 86, 929-943. [CrossRef]

38. Mueller, P.; Patacci, M.; Di Giulio, A. Hybrid event beds in the proximal to distal extensive lobe domain of the coarse-grained and sand-rich Bordighera turbidite system (NW Italy). Mar. Pet. Geol. 2017, 86, 908-931. [CrossRef] 
39. Pierce, C.S.; Haughton, P.D.W.; Shannon, P.M.; Pulham, A.J.; Barker, S.P.; Martinsen, O.J. Variable character and diverse origin of hybrid event beds in a sandy submarine fan system, Pennsylvanian Ross Sandstone Formation, western Ireland. Sedimentology 2018, 65, 952-992. [CrossRef]

40. Kane, I.A.; Pontén, A.S.M.; Vangdal, B.; Eggenhuisen, J.T.; Hodgson, D.M.; Spychala, Y.T. The stratigraphic record and processes of turbidity current transformation across deep-marine lobes. Sedimentology 2017, 64, 1236-1273. [CrossRef]

41. Spychala, Y.T.; Hodgson, D.M.; Lee, D.R. Autogenic controls on hybrid bed distribution in submarine lobe complexes. Mar. Pet. Geol. 2017, 88, 1078-1093. [CrossRef]

42. Kuswandaru, G.Y.; Amir Hassan, M.H.; Matenco, L.C.; Taib, N.I.; Mustapha, K.A. Turbidite, debrite, and hybrid event beds in submarine lobe deposits of the Palaeocene to middle Eocene Kapit and Pelagus members, Belaga Formation, Sarawak, Malaysia. Geol. J. 2019, 54, 3421-3437. [CrossRef]

43. Hofstra, M.; Pontén, A.S.M.; Peakall, J.; Flint, S.S.; Nair, K.N.; Hodgson, D.M. The impact of fine-scale reservoir geometries on streamline flow patterns in submarine lobe deposits using outcrop analogues from the Karoo Basin. Pet. Geosci. 2016, 23, 159-176. [CrossRef]

44. Porten, K.W.; Kane, I.A.; Warchoł, M.J.; Southern, S.J. A Sedimentological Process-Based Approach to Depositional Reservoir Quality of Deep-Marine Sandstones: An Example From the Springar Formation, Northwestern Vøring Basin, Norwegian Sea. J. Sediment. Res. 2016, 86, 1269-1286. [CrossRef]

45. Zhang, L.; Pan, M.; Wang, H. Deepwater Turbidite Lobe Deposits: A Review of the Research Frontiers. Acta Geol. Sin. Engl. Ed. 2017, 91, 283-300. [CrossRef]

46. Jackson, C.A.L.; Zakaria, A.A.; Johnson, H.D.; Tongkul, F.; Crevello, P.D. Sedimentology, stratigraphic occurrence and origin of linked debrites in the West Crocker Formation (Oligo-Miocene), Sabah, NW Borneo. Mar. Pet. Geol. 2009, 26, 1957-1973. [CrossRef]

47. Zakaria, A.A.; Johnson, H.D.; Jackson, C.A.-L.; Tongkul, F. Sedimentary facies analysis and depositional model of the Palaeogene West Crocker submarine fan system, NW Borneo. J. Asian Earth Sci. 2013, 76, 283-300. [CrossRef]

48. Bell, D.; Stevenson, C.J.; Kane, I.A.; Hodgson, D.M.; Poyatos-Moré, M. Topographic Controls On the Development of Contemporaneous but Contrasting Basin-Floor Depositional Architectures. J. Sediment. Res. 2018, 88, 1166-1189. [CrossRef]

49. Brooks, H.L.; Hodgson, D.M.; Brunt, R.L.; Peakall, J.; Hofstra, M.; Flint, S.S. Deep-water channel-lobe transition zone dynamics: Processes and depositional architecture, an example from the Karoo Basin, South Africa. GSA Bull. 2018, 130, 1723-1746. [CrossRef]

50. Soutter, E.L.; Kane, I.A.; Fuhrmann, A.; Cumberpatch, Z.A.; Huuse, M. The stratigraphic evolution of onlap in siliciclastic deep-water systems: Autogenic modulation of allogenic signals. J. Sediment. Res. 2019, 89, 890-917. [CrossRef]

51. Hall, R.; van Hattum, M.W.A.; Spakman, W. Impact of India-Asia collision on SE Asia: The record in Borneo. Tectonophysics 2008, 451, 366-389. [CrossRef]

52. Siddiqui, N.A.; Ramkumar, M.; Rahman, A.H.A.; Mathew, M.J.; Santosh, M.; Sum, C.W.; Menier, D. High resolution facies architecture and digital outcrop modeling of the Sandakan formation sandstone reservoir, Borneo: Implications for reservoir characterization and flow simulation. Geosci. Front. 2019, 10, 957-971. [CrossRef]

53. Usman, M.; Siddiqui, N.A.; Mathew, M.; Zhang, S.; El-Ghali, M.A.K.; Ramkumar, M.; Jamil, M.; Zhang, Y. Linking the influence of diagenetic properties and clay texture on reservoir quality in sandstones from NW Borneo. Mar. Pet. Geol. 2020, 120, 104509. [CrossRef]

54. Usman, M.; Siddiqui, N.A.; Zhang, S.-Q.; Mathew, M.J.; Zhang, Y.-X.; Jamil, M.; Liu, X.-L.; Ahmed, N. 3D Geo-Cellular Static Virtual Outcrop Model and its Implications for Reservoir Petro-physical Characteristics and Heterogeneities. Pet. Sci. 2021. [CrossRef]

55. Ahmed, N.; Siddiqui, N.A.; Ramasamy, N.; Ramkumar, M.; Jamil, M.; Usman, M.; Sajid, Z.; Rahman, A.H.B.A. Geochemistry of Eocene Bawang Member turbidites of the Belaga Formation, Borneo: Implications for provenance, palaeoweathering, and tectonic setting. Geol. J. 2021, 56, 2477-2499. [CrossRef]

56. Sheikh, N.A.; Jamil, M.; Ling Chuan Ching, D.; Khan, I.; Usman, M.; Sooppy Nisar, K. A generalized model for quantitative analysis of sediments loss: A Caputo time fractional model. J. King Saud Univ. Sci. 2021, 33, 101179. [CrossRef]

57. Hall, R. Contraction and extension in northern Borneo driven by subduction rollback. J. Asian Earth Sci. 2013, 76, 399-411. [CrossRef]

58. Mathew, M.J.; Menier, D.; Siddiqui, N.; Ramkumar, M.; Santosh, M.; Kumar, S.; Hassaan, M. Drainage basin and topographic analysis of a tropical landscape: Insights into surface and tectonic processes in northern Borneo. J. Asian Earth Sci. 2016, 124, 14-27. [CrossRef]

59. Siddiqui, N.A.; Mathew, M.J.; Ramkumar, M.; Sautter, B.; Usman, M.; Abdul Rahman, A.H.; El-Ghali, M.A.K.; Menier, D.; Shiqi, Z.; Sum, C.W. Sedimentological characterization, petrophysical properties and reservoir quality assessment of the onshore Sandakan Formation, Borneo. J. Pet. Sci. Eng. 2020, 186, 106771. [CrossRef]

60. Siddiqui, N.A.; Rahman, A.H.A.; Sum, C.W.; Mathew, M.J.; Hassaan, M.; Menier, D. Generic hierarchy of sandstone facies quality and static connectivity: An example from the Middle-Late Miocene Miri Formation, Sarawak Basin, Borneo. Arab. J. Geosci. 2017, 10, 237. [CrossRef] 
61. Ahmed, N.; Siddiqui, N.A.; Rahman, A.H.B.A.; Jamil, M.; Usman, M.; Sajid, Z.; Kamal Zaidi, F. Evaluation of hydrocarbon source rock potential: Deep marine shales of Belaga Formation of Late Cretaceous-Late Eocene, Sarawak, Malaysia. J. King Saud Univ. Sci. 2021, 33, 101268. [CrossRef]

62. Hall, R. Cenozoic geological and plate tectonic evolution of SE Asia and the SW Pacific: Computer-based reconstructions, model and animations. J. Asian Earth Sci. 2002, 20, 353-431. [CrossRef]

63. Jamil, M.; Rahman, A.H.A.; Siddiqui, N.A.; Ahmed, N. Deep marine Paleogene sedimentary sequence of West Sabah: Contemporary opinions and ambiguities. War. Geol. 2019, 45, 198-200.

64. Jamil, M.; Rahman, A.H.A.; Siddiqui, N.A.; Ibrahim, N.A.; Ahmed, N. A contemporary review of sedimentological and stratigraphic framework of the Late Paleogene deep marine sedimentary successions of West Sabah, North-West Borneo. Bull. Geol. Soc. Malays. 2020, 69, 53-65. [CrossRef]

65. Clennell, B. Far-field and gravity tectonics in Miocene basins of Sabah, Malaysia. Geol. Soc. Lond. Spec. Publ. 1996, 106, 307-320. [CrossRef]

66. Cullen, A.B.; Zechmeister, M.S.; Elmore, R.D.; Pannalal, S.J. Paleomagnetism of the Crocker Formation, northwest Borneo: Implications for late Cenozoic tectonics. Geosphere 2012, 8, 1146-1169. [CrossRef]

67. Wang, P.; Li, S.; Guo, L.; Jiang, S.; Somerville, I.; Zhao, S.; Zhu, B.; Chen, J.; Dai, L.; Suo, Y. Mesozoic and Cenozoic accretionary orogenic processes in Borneo and their mechanisms. Geol. J. 2016, 51, 464-489. [CrossRef]

68. Jamil, M.; Siddiqui, N.A.; Umar, M.; Usman, M.; Ahmed, N.; Rahman, A.H.A.; Zaidi, F.K. Aseismic and seismic impact on development of soft-sediment deformation structures in deep-marine sand-shaly Crocker fan in Sabah, NW Borneo. J. King Saud Univ. Sci. 2021, 33, 101522. [CrossRef]

69. Lambiase, J.J.; Tzong, T.Y.; William, A.G.; Bidgood, M.D.; Brenac, P.; Cullen, A.B. The West Crocker formation of northwest Borneo: A Paleogene accretionary prism. Spec. Pap. Geol. Soc. Am. 2008, 436, 171-184.

70. van Hattum, M.W.A.; Hall, R.; Pickard, A.L.; Nichols, G.J. Provenance and geochronology of Cenozoic sandstones of northern Borneo. J. Asian Earth Sci. 2013, 76, 266-282. [CrossRef]

71. Abdullah, W.H.; Togunwa, O.S.; Makeen, Y.M.; Hakimi, M.H.; Mustapha, K.A.; Baharuddin, M.H.; Sia, S.-G.; Tongkul, F. Hydrocarbon source potential of Eocene-Miocene sequence of Western Sabah, Malaysia. Mar. Pet. Geol. 2017, 83, 345-361. [CrossRef]

72. Madon, M. Deep-sea trace fossils in the West Crocker Formation, Sabah (Malaysia), and their palaeoenvironmental significance. Bull. Geol. Soc. Malays. 2021, 71, 23-46. [CrossRef]

73. Usman, M.; Siddiqui, N.A.; Zhang, S.; Ramkumar, M.; Mathew, M.; Sautter, B.; Beg, M.A. Ichnofacies and sedimentary structures: A passive relationship with permeability of a sandstone reservoir from NW Borneo. J. Asian Earth Sci. 2020, $192,103992$. [CrossRef]

74. Prélat, A.; Hodgson, D.M.; Flint, S.S. Evolution, architecture and hierarchy of distributary deep-water deposits: A high-resolution outcrop investigation from the Permian Karoo Basin, South Africa. Sedimentology 2009, 56, 2132-2154. [CrossRef]

75. Shanmugam, G. The hyperpycnite problem. J. Palaeogeogr. 2018, 7, 6. [CrossRef]

76. Brunt, R.L.; Di Celma, C.N.; Hodgson, D.M.; Flint, S.S.; Kavanagh, J.P.; van der Merwe, W.C. Driving a channel through a levee when the levee is high: An outcrop example of submarine down-dip entrenchment. Mar. Pet. Geol. 2013, 41, 134-145. [CrossRef]

77. Groenenberg, R.M.; Hodgson, D.M.; Prelat, A.; Luthi, S.M.; Flint, S.S. Flow-deposit interaction in submarine lobes: Insights from outcrop observations and realizations of a process-based numerical model. J. Sediment. Res. 2010, 80, 252-267. [CrossRef]

78. Zhang, L.-F.; Pan, M.; Li, Z.-L. 3D modeling of deepwater turbidite lobes: A review of the research status and progress. Pet. Sci. 2020, 17, 317-333. [CrossRef]

79. Jamil, M.; Siddiqui, N.A.; Rahman, A.H.B.A.; Ibrahim, N.A.; Ismail, M.S.B.; Ahmed, N.; Usman, M.; Gul, Z.; Imran, Q.S. Facies Heterogeneity and Lobe Facies Multiscale Analysis of Deep-Marine Sand-Shale Complexity in the West Crocker Formation of Sabah Basin, NW Borneo. Appl. Sci. 2021, 11, 5513. [CrossRef]

80. Davis, C.; Haughton, P.; McCaffrey, W.; Scott, E.; Hogg, N.; Kitching, D. Character and distribution of hybrid sediment gravity flow deposits from the outer Forties Fan, Palaeocene Central North Sea, UKCS. Mar. Pet. Geol. 2009, 26, 1919-1939. [CrossRef]

81. Zhang, L.-F.; Dong, D.-Z. Thickening-upward cycles in deep-marine and deep-lacustrine turbidite lobes: Examples from the Clare Basin and the Ordos Basin. J. Palaeogeogr. 2020, 9, 1-16. [CrossRef]

82. Southern, S.J.; Patacci, M.; Felletti, F.; McCaffrey, W.D. Influence of flow containment and substrate entrainment upon sandy hybrid event beds containing a co-genetic mud-clast-rich division. Sediment. Geol. 2015, 321, 105-122. [CrossRef]

83. Lee, S.H.; Jung, W.-Y.; Bahk, J.J.; Gardner, J.M.; Kim, J.K.; Lee, S.H. Depositional features of co-genetic turbidite-debrite beds and possible mechanisms for their formation in distal lobated bodies beyond the base-of-slope, Ulleung Basin, East Sea (Japan Sea). Mar. Geol. 2013, 346, 124-140. [CrossRef]

84. Giacomone, G.; Olariu, C.; Steel, R.; Shin, M. A coarse-grained basin floor turbidite system—the Jurassic Los Molles Formation, Neuquen Basin, Argentina. Sedimentology 2020, 67, 3809-3843. [CrossRef]

85. Hussain, A.; Haughton, P.D.W.; Shannon, P.M.; Turner, J.N.; Pierce, C.S.; Obradors-Latre, A.; Barker, S.P.; Martinsen, O.J. Highresolution X-ray fluorescence profiling of hybrid event beds: Implications for sediment gravity flow behaviour and deposit structure. Sedimentology 2020, 67, 2850-2882. [CrossRef] 